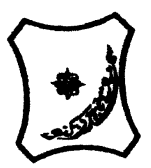

Bayero Journal of Pure and Applied Sciences, 11(1); 91 - 94

Received: January, 2018

Accepted: May, 2018

ISSN $2006-6996$

\title{
ASSESSMENT OF THE EFFECTS OF TEMPERATURE ON THE DEVELOPMENT OF HIDE BEETLE (Dermestes maculatus De Geer 1774)
}

\author{
${ }^{* 1}$ Bala, Z.M., ${ }^{1}$ Majeed, Q. and ${ }^{2}$ Kawo, A.H. \\ ${ }^{1}$ Department of Biological Sciences, Faculty of Science, Usmanu Danfodiyo University, PMB 2346, Sokoto, Nigeria \\ ${ }^{2}$ Department of Microbiology, Faculty of Life Sciences, Bayero University, PMB 3011, Kano, Nigeria \\ *Correspondence Author
}

\section{ABSTRACT}

The present work was carried out to determine the effect of two temperatures $\left(27^{\circ} \mathrm{C}\right.$ and $\left.35^{\circ} \mathrm{C}\right)$ on the development of hide beetle (Dermestes maculatus DeGeer 1774). This research was carried out at the Department of Biological Sciences, Usmanu Danfodio University, Sokoto, 2015. The samples of hide beetle were collected along with the infested dried fish from a local market in Sokoto metropolis, Sokoto State, Nigeria. The adult hide beetles were identified based on morphological features using standard taxonomic key and mother culture was maintained at ambient temperature and humidity. Eggs viability of 92.6\% with 6 larval instars and 82.1 mean pupal survival at $270 \mathrm{C}$ was recorded. This was in comparison with $91.7 \%$ eggs viability, 8 larval instars and mean pupal survival of $86.7 \%$ at 35C. The results showed significant difference for eggs $\left(t_{c a l}\right.$ of $4.4, t_{t a b} 2.78$ at $5 \%$ degree confidence level) larvae ( $t_{c a l}$ of $6.8, t_{t a b}$ at 2.45 at $5 \%$ degree confidence level) and pupae ( $t_{c a l}$ of 7.44 as against $t_{\text {tab }}$ of 2.36).

Keywords: Assessment, Development, Effect, Hide Beet/e, Sokoto, Temperature.

\section{INTRODUCTION}

Dermestes maculatus (DeGeer 1774) belongs to the Phylum Arthropoda, Class Insecta, Order Coleoptera, Family Dermestidae, Genus Dermestes and Species maculatus (McNamara et al., 2008). It is commonly referred to as the hide beetle. The hide beetle feeds on carrion and dry animal products (McNamara et al., 2008). The adult beetles have forensic significance in helping to estimate the post-mortem interval in suicide or homicide cases (Richardson and Goff, 2001). These insects are also pests of the silk industry in Italy and India, and infest stored animal products such as dried fish, cheese, bacon, dog treats and poultry (Veer et al., 1996; Cloud and Collinson, 1986). Hide beetles play an important role in nutrients recycling and are commonly used as "museum volunteers" to clean carcasses as part of skeletonization processing for zoological specimens. The loss caused by hide beetles in dried fish has been attributed to consumer (nutrient quality) resulting to declining consumer acceptability and market price (economic losses) or both (Usman et al., 2012; Odeyemi et al., 2000).

Khan and Khan (2001) reported that at present, total fish production is about 1.2 million tones of which $15 \%$ of fishes are cured for mass people consumption for retailing the dry fish in rainy seasons. It was found that $10-20 \%$ of the stored products lost are due to insect infestation. Coombs (1979) observed the ability of some Dermestes species to develop on vegetable products alone without the presence of an animal protein.In Nigeria, D. maculates is reported to cause $50 \%$ weight loss in dry fish (Kemabonta et al., 2013). Dermestid beetles larvae are very destructive pests of stored products especially hide and skin (Olagunju, 2014). Lale and Sastawa (1996) as well as Odeyemi et al. (2000) recorded about $50 \%$ losses during storage of smoked fish products due to deterioration. This is dependent on length of storage, salt content, climatic conditions and general hygiene practices during processing and storage (Owoade, 2008; Moses, 1983). Lale and Sastawa (1996) also estimated $13-17 \%$ of losses in dried fish during three months of storage mainly by $D$. maculatus. Nigeria produces 150,000 tons of fish products annually of which $40 \%$ is lost due to poor handling and storage with $30-50 \%$ loss in weight (Osuji, 1977; De Young et al., 2011). The main aim of the present research was to study the effects of temperature on hide beetle ( $D$. maculates) with the view of understanding the biology of the pest for its effective and efficient management as it relates to temperature.

\section{MATERIALS AND METHODS}

Collection of Hide Beetle and Food Type Samples This research was conducted in the months of July to October, 2015 in the Department of Biological Sciences, Usmanu Danfodiyo University, Sokoto, Nigeria. The samples of fish species were collected from infested fish stalks in Sokoto Meat, Fish and Vegetable Market. The hide beetle together with the fish debris were picked using soft brush and put into a glass jar covered with muslin cloth and taken to the laboratory for identification using standard taxonomic key and rearing to get mother culture. 
Bajopas Volume 11 Number 1 June, 2018

\section{Identification of the Hide Beetles}

The adult hide beetles were identified based on morphological features as reported by Akinwumi et al. (2000), Haines and Rees (1989) as well as Hinton (1945). Hide beetles are small and dark. Adults are 5-10 $\mathrm{mm}$ and range from dark brown to black in colour. They are strong flyers and are attracted to decaying flesh and rotten meat. Larval forms are very ferocious eaters and pupal forms usually smaller. The identity was further authenticated by comparison with the identified hide beetle specimens preserved in the Museum of the Zoology Unit of the Department of Biological Sciences, Usmanu Danfodiyo University, Sokoto, Nigeria.

\section{Rearing of Mother Culture}

Ten pairs of adult beetles were picked from the stalks brought from the market and transferred to a glass jar $(500 \mathrm{ml})$. Fish food (Clarias gariepinus) was provided to the beetles to feed upon along with the cotton soaked in water to provide drinking water. The jar was covered with muslin cloth tied with rubber band and kept under laboratory conditions for multiplying to produce mother culture.

\section{Preparation of Fish Food}

The fish was sterilized by heating at $60^{\circ} \mathrm{C}$ for one hour in hot air oven in the laboratory in order to kill any insect pest that may be present(Atijegba,2004).

\section{Experimental Design}

The experiment was arranged as completely randomized design (CRD), replicated three times and kept in incubators. The life circle of the pest was determined on To assess the effects of different temperatures $\left(27^{\circ} \mathrm{C}\right.$ and $\left.35 \mathrm{C}^{\circ}\right)$ on the development of the hide beetles, thirty (30) pairs of newly emerged adults were obtained from the mother stalk and were kept in three (3) glass jars. Adults were fed on dried sterilized fish food alongside drinking water. The jar was covered with muslin cloth tied with rubber band. The jar was then kept in an incubator at $27 \pm 2^{\circ} \mathrm{C}$ and relative humidity of $65 \pm 5 \%$. Similar procedure was repeated and the jars were kept at $35 \pm 2{ }^{\circ} \mathrm{C}$ and $65 \pm 5 \%$ relative humidity in another incubator. All experiments were replicated thrice. The observations were made on maturation of adults, egg laying (fecundity), egg incubation, hatchability of eggs (viability), larval development, larval survival, pupal development, pupal survival and adult emergence (Atijegba, 2004).

\section{RESULTS AND DISCUSSION}

(a) Production of Eggs: Table 1 shows that the production and development of eggs was significantly affected by the temperature as the calculated $t$-value was at 4.4 as against 2.78 for t-tabulated. The highest mean number of eggs laid was at temperature of $27^{\circ} \mathrm{C}$ (148) as against temperature of $35 \mathrm{C}^{\circ}$. Incubation period was also affected as it took longer time (4 days) at temperature of $35^{\circ} \mathrm{C}$ than temperature of $27^{\circ} \mathrm{C}$ ( 3 days). Eggs viability was also affected as $92.6 \%$ were viable as observed at temperature of $27^{\circ} \mathrm{C}$ against $91.6 \%$ at temperature of $35^{\circ} \mathrm{C}$. This finding agrees with the work of Richardson and Goff (2001) who worked on survivorship for Dermestes maculatus to be higher between $25^{\circ} \mathrm{C}-30^{\circ} \mathrm{C}$. Similarly, Analdos et al. (2004) reported that full development of Dermestes maculatus is reached only when temperatures are consistently above $18^{\circ} \mathrm{C}$. This is in line with the work of Azeb et al. (1973) that eggs took $1-2$ days at $30^{\circ} \mathrm{C}$ and $10-11$ at $16^{\circ} \mathrm{C}$ to hatch. Eggs and the larval period lasted between 24 days and 96 days at $32^{\circ} \mathrm{C}$ and $19^{\circ} \mathrm{C}$ respectively. Jacob and Fleming (1982) also observed that eggs of $D$. lardarius took 3 days to incubate at $26^{\circ} \mathrm{C}-27^{\circ} \mathrm{C}$ while at $23^{\circ} \mathrm{C}-24^{\circ} \mathrm{C}$ it took 5 days.

(b) Development of Larvae: Table 2 shows that temperature has a significant effect against larval development. This was observed as temperature of $35^{\circ} \mathrm{C}$ recorded the longest mean larval instars of VIII and duration of 28 days as against VI mean larval instars and 23 days at $27^{\circ} \mathrm{C}$. Larval survival was observed in reverse order as low temperature of $27^{\circ} \mathrm{C}$ resulted in shorter survival rate $(32.8 \%)$ as against temperature at $35^{\circ} \mathrm{C}(60.8 \%)$. Temperature is one of the most important factors affecting hide beetles. At higher temperatures above $30^{\circ} \mathrm{C}$, they tend to die out. Their optimum growth temperature is between $25^{\circ} \mathrm{C}-30^{\circ} \mathrm{C}$. The work of Richardson and Goff (2001) who worked on survivorship for Dermestes maculatus individuals reported the highest survival between $25^{\circ} \mathrm{C}-30^{\circ} \mathrm{C}$. Similarly, full development of Dermestus maculates is only reached when temperatures are consistently above $18^{\circ} \mathrm{C}$ as reported by Analdos et al. (2004). Fasunwin et al. (2011) also reported that development of Dermestes maculatus is not possible at $40^{\circ} \mathrm{C}$ or above. Azeb et al. (1963) studied the life history of the beetle at constant temperature and relative humidity and found that incubation, larval and pupal period at $38^{\circ} \mathrm{C}$ and $70 \%$ relative humidity was 2, 28 and 7 days respectively. Azeb et al. (1972) observed that the larval development was affected by both temperature and relative humidity. At $21^{\circ} \mathrm{C}, 27^{\circ} \mathrm{C}$ and $35^{\circ} \mathrm{C}$ (at $75 \%$ relative humidity), development lasted an average of 53, 28 and 20 days respectively while at $27^{\circ} \mathrm{C}$ with lower relative humidity of $55 \%$, the period was increased to 35 days. Larval development of $D$. maculatus was shown by Osuji (1975) to be much more rapid in dried fish than in synthetic media. He further showed that moderate salting $(3.2 \%-10.2 \%$ sodium chloride content) when accompanied by effective dehydration of fish $(6.2 \%$ $9.2 \%$ moisture content) significantly prolonged the larval development period of $D$. maculatus and $N$. rufipes.

(c) Development of Pupae: Table 3 shows the significant effects of temperature on pupal development. Longer pupal duration was observed at temperature of $35^{\circ} \mathrm{C}$ ( 6 days) as against temperature of $27^{\circ} \mathrm{C}$ (4 days). Pupal survival rate was observed in reverse order as temperature of $35^{\circ} \mathrm{C}$ has a mean pupal survival rate of $86.7 \%$ against temperature of $27^{\circ} \mathrm{C}$ (82.7\%). Azeb et al. (1973) reported the pupal duration at 5.1 days (ranging from $2-11$ days) at $29^{\circ} \mathrm{C}$, the pre-oviposition period was 3 days at $35^{\circ} \mathrm{C}$ and 19 days at $21^{\circ} \mathrm{C}$. James $(1980)$ observed the rate of development of $D$. maculatus at different temperatures. 
It was further noted that the eggs at $26^{\circ} \mathrm{C}-27^{\circ} \mathrm{C}$ took 3 days for incubation, while at $23^{\circ} \mathrm{C}-24^{\circ} \mathrm{C}$ they took 5 days. Larval duration at $23^{\circ} \mathrm{C}$ was recorded as

44 days. Pupal development occurred within 35 days during winter when the

temperature was very low, but at $20^{\circ} \mathrm{C}-25^{\circ} \mathrm{C}$, they took 14 days. The total development duration according to $\mathrm{Him}$, at $28^{\circ} \mathrm{C}-30^{\circ} \mathrm{C}$ was $42-46$ days, while at $23^{\circ} \mathrm{C}$ it was 55 days. He further observed that the duration may increase up to several years under adverse or unfavourable weather conditions.

\begin{tabular}{ccccccc}
\multicolumn{6}{c}{ Table 1: Eggs Production by Adults of Hide Beetle (D. maculatus) at Different Temperatures Fed on Fish Food } \\
\hline Adult Pairs & $\begin{array}{c}\text { Temp } \\
\left({ }^{\circ} \mathrm{C}\right)\end{array}$ & $\begin{array}{c}\text { Mean } \\
\text { Number of } \\
\text { eggs laid }\end{array}$ & $\begin{array}{c}\text { Mean Incubation } \\
\text { period (days) }\end{array}$ & $\begin{array}{c}\text { Mean number } \\
\text { of eggs } \\
\text { hatched (viable } \\
\text { eggs) }\end{array}$ & $\begin{array}{c}\text { Viability of } \\
\text { eggs } \\
(\%)\end{array}$ & $\begin{array}{c}\text { Non viability of } \\
\text { eggs } \\
(\%)\end{array}$ \\
\hline 10 & $35^{\circ} \mathrm{C}$ & 131 & 4 & $120 \pm 2.62$ & 91.6 & 8.4 \\
10 & $27^{\circ} \mathrm{C}$ & 148 & 3 & $137 \pm 1.7$ & 92.6 & 7.4 \\
\hline
\end{tabular}

*Values are means of three replicates $\pm \mathrm{SE}$, within each row; means having the same letters in their superscripts are not significantly different from each other at $5 \%$ significance level.

Table 2: Larval Development at Different Temperatures Fed on Fish Food

\begin{tabular}{|c|c|c|c|c|c|c|c|c|c|c|c|c|}
\hline \multirow{2}{*}{$\begin{array}{c}\text { Date and } \\
\text { number of } \\
\text { larvae }\end{array}$} & \multirow[t]{2}{*}{$\begin{array}{l}\text { Temp } \\
\left({ }^{\circ} \mathrm{C}\right)\end{array}$} & \multicolumn{8}{|c|}{$\begin{array}{l}\text { Mean number of larval instars } \\
\text { (Mean larval duration in days) }\end{array}$} & \multirow[t]{2}{*}{$\begin{array}{l}\text { Mean number of } \\
\text { larvae pupated }\end{array}$} & \multirow[t]{2}{*}{$\begin{array}{c}\text { Mean larval } \\
\text { duration (days) }\end{array}$} & \multirow{2}{*}{$\begin{array}{c}\text { Mean larval } \\
\text { survival } \\
(\%)\end{array}$} \\
\hline & & I & II & III & IV & $\mathrm{V}$ & VI & VII & VIII & & & \\
\hline $\begin{array}{l}10 / 09 / 2015 \\
120\end{array}$ & $35^{\circ} \mathrm{C}$ & $\begin{array}{l}120 \\
(5)\end{array}$ & $\begin{array}{l}104 \\
(3)\end{array}$ & $\begin{array}{l}103 \\
(3)\end{array}$ & $\begin{array}{l}93 \\
(4)\end{array}$ & $\begin{array}{l}89 \\
(5)\end{array}$ & $\begin{array}{l}83 \\
(6)\end{array}$ & $\begin{array}{l}82 \\
(7)\end{array}$ & $\begin{array}{l}73 \\
(8)\end{array}$ & $67 \pm 2.85$ & 28 & 60.8 \\
\hline $\begin{array}{l}13 / 09 / 2015 \\
137\end{array}$ & $27^{\circ} \mathrm{C}$ & $\begin{array}{l}128 \\
(2)\end{array}$ & $\begin{array}{l}122 \\
(3)\end{array}$ & $\begin{array}{l}117 \\
(4)\end{array}$ & $\begin{array}{l}110 \\
(4)\end{array}$ & $\begin{array}{l}106 \\
(6)\end{array}$ & $\begin{array}{l}45 \\
(7) \\
\end{array}$ & & & $39 \pm 1.69$ & 23 & 32.8 \\
\hline
\end{tabular}

*Values are means of three replicates $\pm \mathrm{SE}$, within each row; means having the same letters in their superscripts are not significantly different from each other at $5 \%$ significance level.

\begin{tabular}{|c|c|c|c|c|}
\hline $\begin{array}{c}\text { Number of Pupae } \\
\text { observed }\end{array}$ & $\begin{array}{c}\text { Temp. } \\
\left({ }^{\circ} \mathrm{C}\right)\end{array}$ & $\begin{array}{l}\text { Mean number } \\
\text { of adults } \\
\text { emerged }\end{array}$ & $\begin{array}{l}\text { Mean pupal } \\
\text { survival (\%) }\end{array}$ & $\begin{array}{c}\text { Mean pupal } \\
\text { duration (days) }\end{array}$ \\
\hline 67 & $35^{\circ} \mathrm{C}$ & $58 \pm 5.5$ & 86.7 & 6 \\
\hline 39 & $27^{\circ} \mathrm{C}$ & $32 \pm 2.1$ & 82.1 & 4 \\
\hline
\end{tabular}

*Values are means of three replicates $\pm \mathrm{SE}$, within each row; means having the same letters in their superscripts are not significantly different from each other at $5 \%$ significance level. 


\section{CONCLUSION}

Based on the current findings, lower temperature of $27^{\circ} \mathrm{C}$ is more favourable for the development with $92.6 \%$ viability of eggs produced compared to $91.6 \%$ at $35^{\circ} \mathrm{C}$, hence a significant difference when t-calculated of 4.4 against t-tabulated of 2.78. Six (6) larval instars with 39 mean larvae pupated at $27^{\circ} \mathrm{C}$ to 8 larval instars

\section{REFERENCES}

Akinwumi, F. O.,Fasakin, E. A. and Adedire, C. O. (2006): Progeny inhibiting effects of four plant products against the leather beetles and the copra battle of smoked African mudfish. Journal of Biological Sciences 6 (6):1023-1028.

Analdos, M. L: Sanchez, F: Alvarez, P. and Garcia, M. D. (2004): A Forensic Entomology case from the South-eastern Liberian Peninsular. Aggrawal's Internet Journal of Forensic Medicine and Toxicology 5: 22-25.

Altijegba, S. R. (2004). Infestation of smoked fish in Ghana. M.Phil Thesis in Entomology, University of Ghana, Pp103.

Azeb, A. K: Tawfik, M. F. S. and Abduzeid, N. A. (1973): The Biology of Dermestes maculatus. Bulletin Societe Entomologique d' Egypte 56 : 2 - 4.

Cloud, J. A. and Collinson, C. H. (1986): Comparison of various poultry house litter components for hide beetle Dermestes maculatus (DeGeer) larval development in the Laboratory. Poultry Science 65:1911-1914.

Coombs, C. W. (1979): The Effects of temperature and relative humidity upon the development and fecundity of $D$. PeruviansLaposter de Casrwlnan (Coleoptera; Dermestidae). Journal of Stored Products and Research 15:43-53.

De Young, C: Sheridan, S: Davies S. and Hjort, A. (2011): Climate change implications for fishing communities in the Lake Chad Basin. FAO Fisheries and Aquaculture Proceedings. Rome, FAO. No. 25: 84pp.

Fasunwin, B. T: Banjo, A. A. and Jemine, T. A. (2011): Effects of Dermestes maculatus on the nutritional qualities of two edible insects (Oryctes boas and Rhynchophorus phuenicis). African Journal of Food Agriculture Nutrition and Development 11(7): 5600-5613.

Haines, C. P. and Rees, D. P. (1989): Dermestes spp: $A$ field guide to the types of insects and mite infesting cured fish http://www.fao.org/docrep/003/t0146e/T0146E04

Hinton, H. E. (1945). A monograph of beetles associated with stored products, volume 1. British museum (National History). England. Pp 261-268.

Jacob, T.A. and Fleming. D.A. (1982): Observation on the influence of free water on the fecundity and longevity of $D$. lardarius. Entomologist Monthly Magazine 118:127- 231.

James, R. B. (1980). The Biology and Control of Insect Pests of Medical Importance. $3^{\text {rd }}$ Edition, Belhaven Press, London, 409-412pp.

Khan, M. A. A. and Khan, Y. S. A. (2001): Insects Infestation and Preventive measures in Dry fish, Storage of with 67 mean larvae pupated at $35^{\circ} \mathrm{C}$ given a significant difference of 6.8 as against t-tabulated of 2.45 . Similarly, a significant difference at the pupal level with temperature of $27^{\circ} \mathrm{C}$ and $35^{\circ} \mathrm{C}$ recording a t-calculated value at 7.44 while t-tabulated was 2.36 . Hence, it could be concluded that temperature has no significant difference, all at $5 \%$ confidence level.

Bangladesh. Online Journal of Biological Sciences1 (10):963-965.

Kemabonta, K. A: Makanjoula, W. A. and Omogunloye, O. A. (2013): Evaluation of Spintor Dust in the Protection of Dried Tilapia niloticus against Dermestes maculatus DeGeer (Coloeptera: Dermestidae). Journal of Natural Science Research 3(4):51-59.

Lale, N. S. E. and Sastawa, B. M. (1996): The effects of Sun drying on the infestation of the African Catfish (Clarias gariepinus) by post harvest insect in the Lake Chad District of Nigeria. International Journal of Pest Management 42:281283.

McNamara, K. B: Brown, R. L: Elgar, M. A. and Jones, T. M. (2008). Paternity costs from polyandry compensated by increased fecundity in the hide beetle. Behavioural Ecology, 19: 433-440.

Moses, B. S. (1983): Problems and prospects of artisanal fisheries in Nigeria. Pp 76-90. In: Proceedings of Second Annual Conference of the Fisheries Society of Nigeria. Calabar, January, 1983.

Odeyemi, O. O: Owoade, R. A. and Akinkurolere, O. (2000): Toxicity and population suppression effects of Parkia clappatonianaon dried fish pest (Dermestesmaculatus and Necrobia rufipes). Global Journal of Pure and Applied Science 6:191-195

Olagunju, J. O. O. (2014): Effects of two eco-friendly insecticides (Dennetiatripetals and Piper guineenns) against Dermestes maculatus (DeGeer) on smoked dried fish Clariasgariepinus (Pisces: Claridae). Journal of Environmental Science, Toxicology and Food Technology 8(7):37-43.

Osuji, F. N. C. (1977): The development of Necrobia rufipes in dried fish and certain other commodities. Nigerian Journal of Sciences 15:21-32.

Owoade, R. A. (2008):Storage of dried fish, Clarias lazera (Curvier and Valencienses) in different packaging materials and control of the major pest Dermestes maculatus(DeGeer). M. Tech. Thesis, University of Technology, Akure, Nigeria. Pp. 54.

Richardson, M. S. and Goff, M. L. (2001): Effects of temperature and Intra-specificinteraction on the development of Dermestes maculatus (Coleoptera: Dermestidae).

Usman, Z: Janathan, N. A. and Millicent, A. C. (2012): Development of Dermestes maculatus (DeGeer) on different fish substrate. Jordan Journal of Biological Science .6(1):5-10.

Veer, V: Neg, B. K. and Rao, K. M. (1996): Dermestid beetles and some other insect pest associated with stored silkworm cocoons in India, including a world list of dermestid species found attacking this commodity. Journal of Stored Products ～Research 32:69-89. 